\title{
I See Golden Mussel! They are Everywhere! Environmental DNA Supports Widespread Dissemination of Limnoperna fortunei in Hydrographic Basins in the Paraná State, Brazil.
}

\author{
Patricia Dammski Borges de Andrade ${ }^{1^{*}}$ \\ https://orcid.org/0000-0002-3799-3996
}

Emanuel Razzolini²

https://orcid.org/0000-0002-9391-5271

\section{Rafael Antunes Baggio 2}

https://orcid.org/0000-0001-8307-1426

${ }^{1}$ Instituto de Tecnologia Para o Desenvolvimento - Lactec, Curitiba, Paraná, Brazil; ${ }^{2}$ Baggio Tecnologia e Meio Ambiente, Curitiba, Paraná, Brazil.

Editor-in-Chief: Alexandre Rasi Aoki

Associate Editor: Camila Fediuk de Castro Guedes

Received: 2021.03.10; Accepted: 2021.08.27.

*Correspondence: patricia.borges@lactec.org.br; Tel.: +55-41-995081331 (P.D.B.A)

\section{HIGHLIGHTS}

- Golden mussel distribution in Paraná, Brazil, through eDNA and previous records.

- 90 from 178 sampled sites with Limnoperna fortunei DNA presence.

- Present and previous records support the species occurrence in 118 widespread sites.

- A worrying scenario and urgent need for prevention, mitigation, and impact control.

\begin{abstract}
The golden mussel is an aquatic invasive species that was introduced in South America in the '90s, including Brazil, and was firstly registered in 2001 in the Paraná state. This bivalve causes macrofouling issues because adhere in substrates and form dense aggregations, affecting especially hydroelectric power plants, and water treatment facilities, apart from the native biodiversity. The present research aimed to diagnose the distribution of Limnoperna fortunei in the Paraná state using environmental DNA (eDNA) from 174 sites from 12 basins, and scientific and technical previous records. L. fortunei eDNA was found in 90 sites from 11 hydrographic basins sampled. Most of the positive samples were detected in Iguaçu (42), Tibagi (15), and Ivaí (10) rivers basins. We also registered the first occurrence for five basins: Cinzas, Itararé, Ivaí, Pirapó e Ribeira rivers. Together, our and previous data recorded L. fortunei in 118 sites, between adult, larvae, and eDNA detection. Moreover, the results evidenced that eDNA is a low coast and reliable tool, and it may be very recommended for $L$. fortunei early detection and diagnosis. The present research was the greatest and most widespread survey for golden mussel prospection in a state in Brazil, supported a worrying scenario for Parana, with the urgent need for intense and continuous monitoring and prevention actions for controlling and mitigation of the $L$. fortunei impacts.
\end{abstract}


Keywords: bioinvasion; biofouling; macrofouling; aquatic eDNA; mussel; bivalve.

\section{GRAPHICAL ABSTRACT}

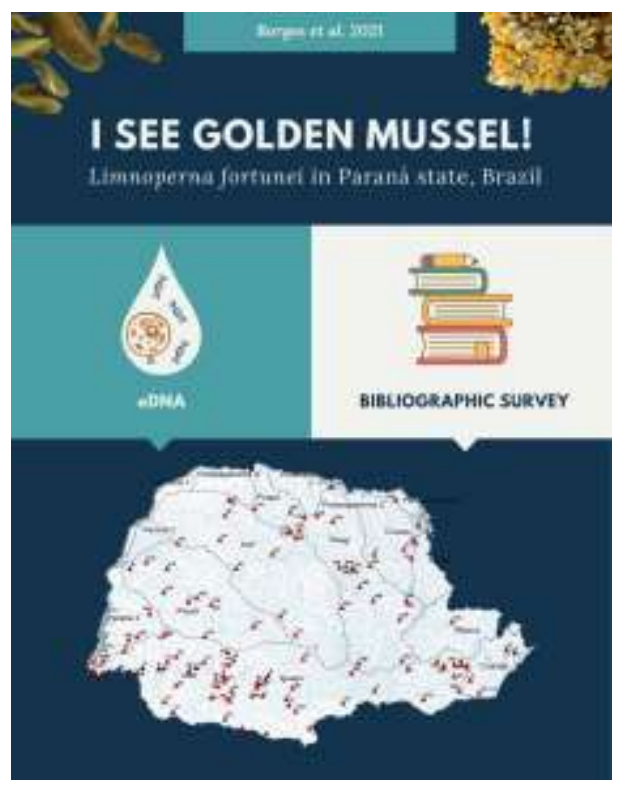

\section{INTRODUCTION}

The golden mussel, Limnoperna fortunei, is an aquatic invasive mussel original from Southeast Asia that was introduced in South America in 1991, probably through ballast water [1]. The species expanded their distribution and have spread throughout a lot of hydrographic basins in many countries, including Brazil [2][7]. Limnoperna fortunei is a macrofouling organism (i.e. they attach to natural and artificial substrates), and cause deep environmental [7], [8] and economic impacts. At industrial facilities, hydroelectric power plants (HPP) and water treatment facilities are among the most affected by fouling mussels, like Dreissena polymorpha in the United States [9]. L. fortunei populations can obstruct filters and heat exchange equipment, generate pipe diameter and water velocity reduction, increase corrosion processes, deterioration of materials, among other impacts [2], [8], [9]. Densities can reach 240,000 individuals $/ \mathrm{m}^{2}$, and the consequences of the golden mussel fouling are the increase in cost by equipment efficiency loss, increase in manpower need for maintenance and cleaning, as well as operational risks [7], [10].

Once golden mussel is introduced and became established, it is difficult or even impossible to eradicate a population [8]. Many efforts have been made intending to avoid the macrofouling inside the facilities and to control its impacts (e.g. [10]-[15]). Among all of them, chemicals like chlorine and the commercial biocide MXD100 [16], [17] have been widely tested and used in power plants in Brazil, but despite the good results, they have potential to cause environmental damages (e. g. [18], [19]), and its long-term as well as synergistic effects are unknown. Thus, prevention is the best alternative, decreasing the environmental and economic costs [8] and so, monitoring and early detection methods have been the focus of many researches (e. $\mathrm{g}$. [20]-[23]).

Traditional techniques are widely used for monitoring and studying these species, through plankton samples and optical analysis for larval stages, and different kinds of substrates, visual inspections and specimens collection for adults, both in water bodies and inside facilities [5], [24]-[27]. DNA-based methods provide the advantage of efficiency, speed, and accuracy of the invasive species detection [28]. The first molecular marker specific for $L$. fortunei was a mitochondrial DNA fragment for detecting larvae in plankton samples [29], [30]. More recently, methodologies have been developed based on environmental DNA (or eDNA) detection (the presence of genetic material in the environment, so it can be accessed without the need to collect or capture individuals) [31], [32]. Thus, the low cost eDNA method presents a key tool for the early detection of invasive species (i.e. before the settlement of the population), what permits a proactive, more efficient and cost-effective management of these populations. This technique has been used to monitor the presence and distribution of several organisms, like insects, fishes, amphibians, mammals, and mussels [32], [33], [42], [43], [34]-[41], and molecular markers for L. fortunei eDNA detection have already been developed [44], [45]. 
In Brazil, the golden mussel was first reported in 1998 at Mato Grosso State, upper Paraguay River Basin, and in the same year at the Rio Grande do Sul state, in the delta of Jacuí River [7], [46]. The first power plant that registered the species was Itaipu HPP, Paraná River, in 2001 [47]. That was one of the first occurrences of the species in Paraná, along with another record on the opposite side of the state, in the same year, near Curitiba City, in two reservoirs, Piraquara I and Guaricana [48]. In these last two sites, meantime, the species has never been recorded again and could be a case of failure in the invasion process, but there was scarce information in the initial report to allow an in-depth analysis [49]. Since then, L. fortunei has spread throughout other rivers of the Paraná Basin and was reported in almost the entire length of Iguaçu River [24], [50], [51], and in localized points in Piquiri and Tibagi rivers [50], [51]. In the stretches of Paraná and Paranapanema rivers in the borders of the state, the L. fortunei populations are established [2], and in the last one, the species was recorded for the first time in 2006 and spread over it, affecting at least six power plants [17], [52].

The objective of this study was to carry out an extensive prospection of the of golden mussel occurrence and distribution in the state of Paraná, through eDNA detection in water samples collected in reservoirs and water treatment plants, complemented with a bibliographic survey. Frequently, the studies and monitoring are punctual, concentrated in some stretches of rivers, or the coverage area of the power plants and other facilities. The present survey is the most widespread diagnosis about the L. fortuneioccurrence and distribution ever performed in the state of Paraná and probably in any other state of the country.

\section{MATERIAL AND METHODS}

The prospection of $L$. fortunei presence in the Paraná, Brazil watersheds was assessed through eDNA approach with samplings along most of the state and complemented with papers and technical reports that recorded the presence of the species.

\section{Sample collection}

The total of 199 environmental DNA (eDNA) samples from 174 sites in rivers, reservoirs and Water Treatment Stations (WTSs) from Paraná state, Brazil were collected between 2018 and 2019 (Figure 1, Table 1 , SI A). This sampling comprises $146(37 \%)$ of the 399 counties of the state and 12 different basins. These basins sum 188 thousand $\mathrm{km}^{2}$, about $94 \%$ of the Paraná state total area (199 thousand $\left.\mathrm{km}^{2}\right)$. The 100-300 $\mathrm{ml}$ water samples were collected preferably close to the substrate, which was disturbed to resuspend deposited particles, maximizing the success of eDNA species detection. According to [45], this method presents superior detection efficiency than samplings superficial layers. Sampling carried out in 2019 included three different points per sampling site $(3 \times 100 \mathrm{ml})$, and samples were subsequently concentrated in a single bottle, for increasing the probability of $L$. fortunei eDNA detection. Samples were stored in DNA/RNA-free vials and frozen as soon as possible for posterior laboratory procedures.

\section{eDNA filtering}

In the laboratory, samples were processed in a room specially prepared with ultra-violet light to reduce the risk of contamination. One hundred milliliters of each sample were filtered with cellulose nitrate membrane filter with $0.45 \mu \mathrm{m}$ pores in a Glass Filtration kit. Each filter with the filtered material was placed in a $1.5 \mathrm{ml}$ Eppendorf tube for total DNA extraction. Between the filtering of the samples, both the filtration system and the room were completely decontaminated with water, detergent, bleach, and ethanol to eliminate contamination risks for the next step of the process.

\section{Molecular analysis}

The total DNA extraction of each sample was performed using an EZ-DNA extraction kit (Biosystems, Brazil). Then, the extracted DNA amount and purity were measured in Nanodrop 1000 (Thermo Fisher Scientific). The success of total DNA isolation and absence of PCR inhibitors were tested by a PCR reaction using the universal markers $1100 \mathrm{~F}$ and PACEB/1270-R [53], that amplifies an approximately 200 bp fragment of the ribosomal region 18S. Each reaction was optimized for a total of $25 \mu \mathrm{l}$ with $2 \mu \mathrm{l}$ of DNA template, $3 \mathrm{mM}$ of $\mathrm{MgCl}_{2}, 1 \mathrm{x}$ of PCR-Buffer, $0.4 \mathrm{mM}$ of dNTP, 0.5 pmoles of each marker, $1 \mathrm{U}$ of Platinum Taq DNApolymerase (Invitrogen), and ultrapure water until completing the final volume of $25 \mu \mathrm{l}$. The PCR program followed an initial denaturation cycle at $95^{\circ} \mathrm{C}$ for $5 \mathrm{~min}$, followed by 35 cycles of $94^{\circ} \mathrm{C}$ for $30 \mathrm{~s}, 58^{\circ} \mathrm{C}$ for $30 \mathrm{~s}$ of annealing, extension to $72^{\circ} \mathrm{C}$ for $30 \mathrm{~s}$, and a final extension cycle at $72^{\circ} \mathrm{C}$ for $5 \mathrm{~min}$. The amplified products were visualized by electrophoresis in 1.5\% agarose gel, colored with GelRed (Biotium), and revealed in ultra- 
violet light. Samples with negative results for the universal marker were filtered again, reextracted, and had their PCR remade. Positive (to ensures the success of the reactions) and negative (to assess contaminations) controls were added in all reactions. The negative control receives all the reagents but no DNA template is added. The positive control is composed of an adult golden mussel DNA sample.

The presence of $L$. fortunei eDNA was assessed by PCR technique with the primers COI-BF, fluorescently marked with 5-FAM, and COI-BR [54]. The recipe and PCR program followed the same protocol

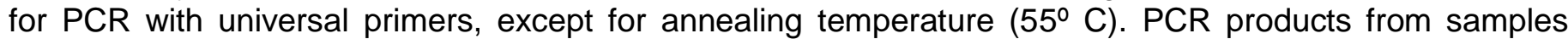
collected in 2018 were visualized in agarose gel electrophoresis dyed with GelRed (Biotium), and dubious agarose gel results were submitted to an $A B I 3130$ sequencer to confirm the detection. All PCR result from sampled collected in 2019 was visualized in the ABI 3130 sequencer. The use of the sequencer allows greater detection sensitivity of positive PCR results than electrophoresis in agarose gel. To avoid false-positive results, only peaks with intensities greater than 1,000 were considered positive. In this step, positive and negative controls were also included in all reactions. For confirming the identifications, two positive samples were sequenced for the COI mDNA gene. For it, PCR was reperformed using the same conditions above described, except by the non-labeled COI-BF. The positives PCR products were purified using the MinElute (Qlagen) and submitted to the sequencing reaction using the BigDye v 3.1 Kit (Applied Biosystem) according to manufacture protocol. Sequencing was performed with the ABI 3130 sequencer (Applied Biosystem). The

resulting sequences were edited using Geneious 4.8.5 and deposited in GenBank (https://www.ncbi.nlm.nih.gov/genbank/) under access numbers MW702727 and MW702728. The identifications were performed using the Identification Engine tool in the BOLDSystems - Barcode of Life Database Systems [55].

\section{Bibliographic Survey}

The previous occurrence of $L$. fortunei in Paraná basins, at any time since 1991 (year of the first species record in South America), was accessed through a bibliographic survey of papers, scientific and technical reports in Periódicos Capes, Web of Science, and Scielo gateways. The following index was used: Limnoperna fortunei, golden mussel, "mexilhão-dourado" and "mexilhão dourado", each one combined (using "AND" between the keywords) with the name of the state (Paraná) and the hydrographic basins: Paraná, Iguaçu, Paranapanema, Ivaí, Piquiri, Tibagi, Itacaré, Cinzas, Pirapó, Ribeira and coastal basin (as well as "bacia litorânea"). These terms were sought into papers title, abstract, and keywords. Considering that exists regional publications possible not available on these search platforms, technical reports were also searched on the Google search tool. We considered only water bodies from Paraná state domain, excluding the main channel of the Paraná and the Paranapanema rivers because both are boundaries between the state of Paraná and Mato Grosso do Sul as well as Paraguay, and São Paulo state respectively. Moreover, the golden mussel populations in these rivers are well established [2]. The survey was carried out in February 2021.

\section{RESULTS}

A total of 182, out of 199 collected samples, were positive for universal eDNA (hereafter named preserved samples). The remaining 17 samples did not have the universal DNA detected (inconclusive samples), but the majority of them were repeated, and only three sites have inconclusive results at the end. Among the preserved samples, 99 samples (54\% of the preserved samples) from 90 sites (50\% of the sites with preserved samples) and 77 counties (53\% of the sampled counties with preserved samples) were positive for $L$. fortunei DNA presence (Figure 1, Table 1, Supplementary Table 1). Most of the positive samples were detected in Iguaçu River (42), Tibagi River (15), and Ivaí River (10) basins. The basins with a higher prevalence of positive samples (number of positive samples/numbers of preserved samples), despite the small number of sample points, were Paranapanema River I and Ribeira River basins (100\%). Among the main collected basins (more than five samples in the same basin), the Piquiri River and Paraná III basins presented the highest prevalence (89\%) followed by Pirapó River basin (86\%). Ivaí River and Tibagi River basins presented $48 \%$ and $39 \%$ of the samples with $L$. fortunei DNA presence. In the Iguaçu River basin, $56 \%$ of the samples were positive, with higher prevalence in its Lower (64\%) and Medium (67\%) portions. Moreover, 38\% of the samples collected in the Upper Iguaçu River had L. fortunei eDNA detected. The sequenced samples were identified as $L$. fortunei with $100 \%$ of probability.

Apart from our eDNA survey, eight scientific papers and one technical report recorded other $28 \mathrm{~L}$. fortunei occurrences, 20 of them from the Iguaçu River basin, three from each Tibagi River basin and Coastal basins, and two from Piquiri River (Figure 2, Table 1, Supplementary Table 2). Thus, our and previous published 
data support the occurrence of $L$. fortunei in 118 widespread distributed sites in most Paraná state basins (Figure 2).

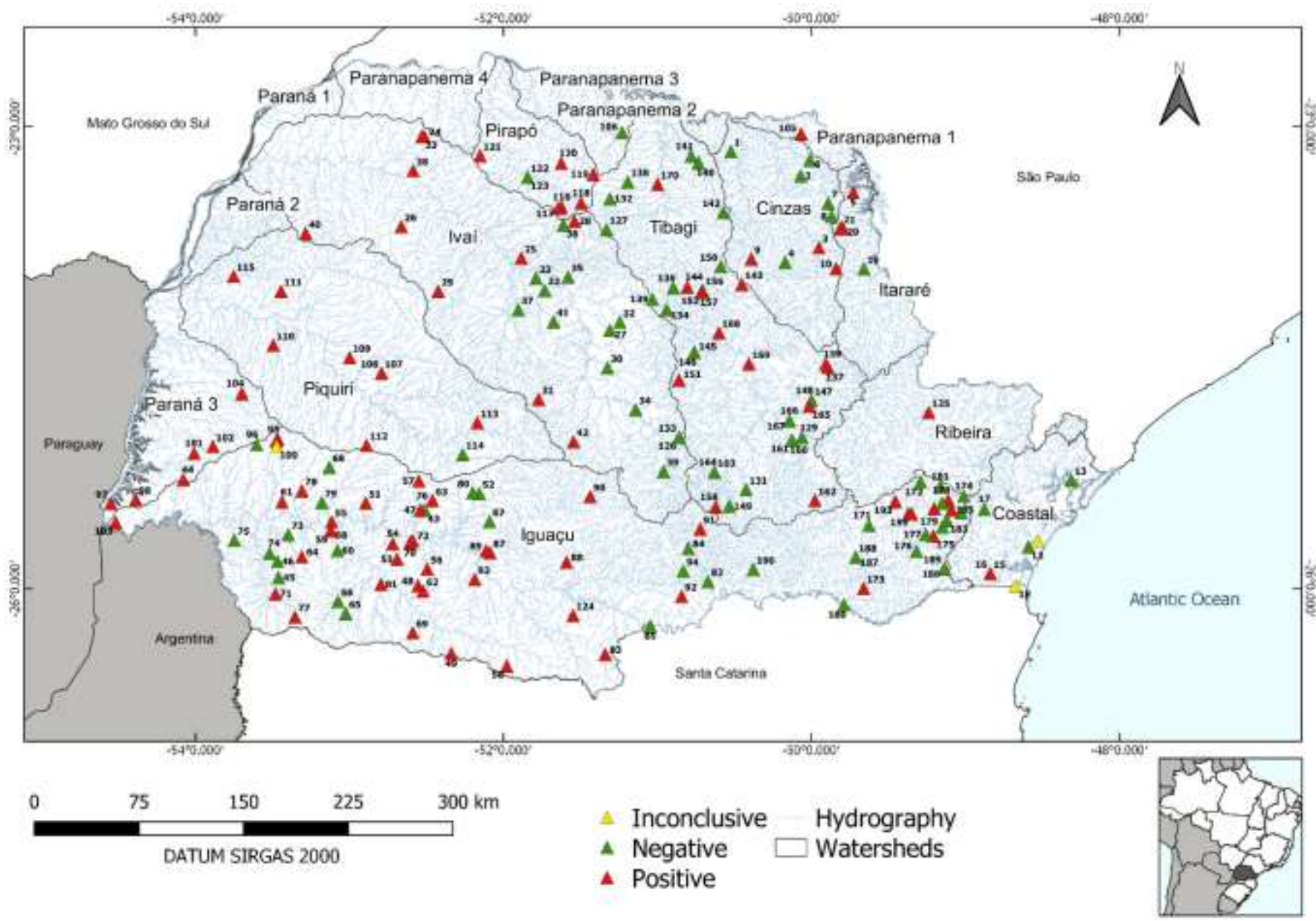

Figure 1. Sampling sites in water bodies from Paraná state and the detection of Limnoperna fortunei eDNA. Inconclusive samples represent those that was negative for universal DNA marker.

Table 1. Basins sampled, their total drainage area, numbers of collected and preserved samples, number and percentage of positive samples for $L$. fortunei eDNA, and the number of species reports in the bibliography in the Paraná state, Brazil.

\begin{tabular}{|c|c|c|c|c|c|c|c|}
\hline ID & Basin & $\begin{array}{c}\text { Area } \\
\left(\mathrm{km}^{2} \times 10^{3}\right)\end{array}$ & Samples & $\begin{array}{l}\text { Preserved } \\
\text { Samples }\end{array}$ & $\begin{array}{l}\text { Positive } \\
\text { Samples }\end{array}$ & $\begin{array}{c}\% \\
\text { Positive } \\
\text { Samples } \\
\end{array}$ & $\begin{array}{l}\text { Previous } \\
\text { Records }\end{array}$ \\
\hline 1 & Cinzas & 9.6 & 11 & 11 & 4 & $36 \%$ & 0 \\
\hline 2 & Coastal & 5.6 & 7 & 5 & 1 & $20 \%$ & 3 \\
\hline 3 & Itararé & 4.8 & 3 & 3 & 2 & $67 \%$ & 0 \\
\hline 4 & Ivaí & 36.5 & 21 & 21 & 10 & $48 \%$ & 0 \\
\hline 5 & Iguaçu & 54.8 & 81 & 75 & 42 & $56 \%$ & 20 \\
\hline \multicolumn{3}{|c|}{ Lower Iguaçu } & 39 & 39 & 25 & $64 \%$ & 10 \\
\hline \multicolumn{3}{|c|}{ Medium Iguaçu } & 13 & 12 & 8 & $67 \%$ & 7 \\
\hline \multicolumn{3}{|c|}{ Upper Iguaçu } & 29 & 24 & 9 & $38 \%$ & 3 \\
\hline 6 & Paraná III & 8.0 & 10 & 9 & 8 & $89 \%$ & 0 \\
\hline 7 & Paranapanema I & 1.2 & 1 & 1 & 1 & $100 \%$ & 0 \\
\hline 8 & Paranapanema III & 3.6 & 1 & 1 & 0 & $0 \%$ & 0 \\
\hline 9 & Piquiri & 24.2 & 9 & 9 & 8 & $89 \%$ & 2 \\
\hline 10 & Pirapó & 5.1 & 8 & 7 & 6 & $86 \%$ & 0 \\
\hline 11 & Ribeira & 9.7 & 2 & 2 & 2 & $100 \%$ & 0 \\
\hline \multirow[t]{2}{*}{12} & Tibagi & 24.9 & 45 & 38 & 15 & $39 \%$ & 3 \\
\hline & Total & 188.2 & 199 & 182 & 99 & $54 \%$ & 28 \\
\hline
\end{tabular}




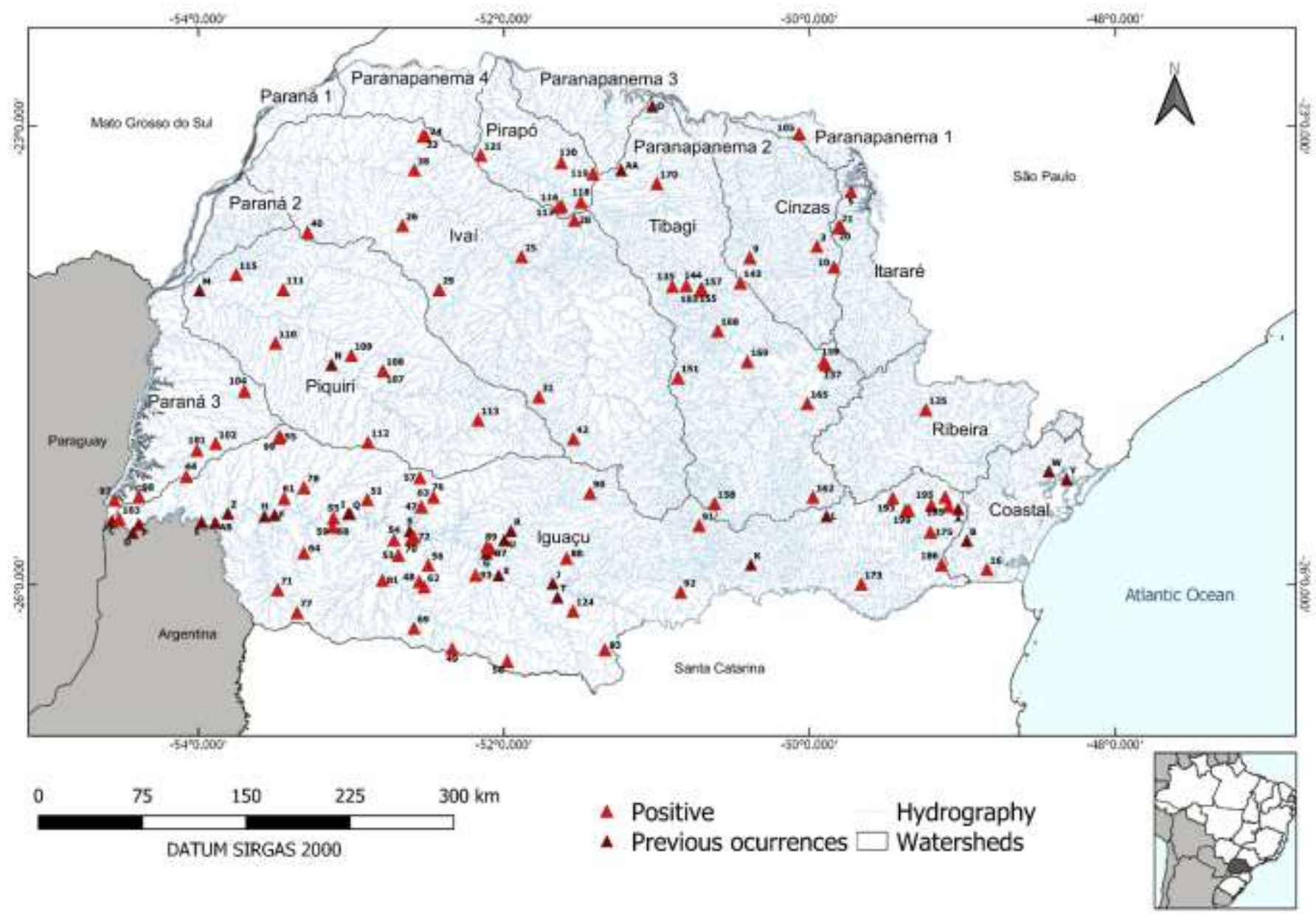

Figure 2. Limnoperna fortunei distribution along Paraná state watersheds based on eDNA (present research), larvae and adult detection (previous occurrences).

\section{DISCUSSION}

In this study, we performed the most extensive detection study of Limnoperna fortunei in Paraná state, and found evidence for its presence, trough eDNA detection, in 90 sites along 77 counties and 11 basins that represent $94 \%$ of the Paraná area. Until the present survey, according to the bibliography, there were 28 sites with the $L$. fortunei occurrence inside the state, between adults and larvae detection (optical and molecular method), in the entire length of Iguaçu river, in Piquiri, Tibagi and Coastal basins [17], [24], [48], [51], [56]-[60]. In the Iguaçu River, the species has been found inside the Iguaçu National Park, since 2005 [17], [24], [51], [58], [60], which raises great concern about the possible environmental impacts.

The present data records the first occurrence for five other hydrographic basins: Cinzas, Itararé, Ivaí, Pirapó e Ribeira rivers. Apart of the main channel of Paraná and Paranapanema rivers, this was the first occurrence for inland waters for Paraná III and Paranapanema I basins. We also reported a new occurrence of $L$. fortunei in the Melo River in the Coastal basin. The occurrence of this species in coastal rivers has already been described for the Paranagua Bay microbasins [58], a region with high ecological importance with extensive environmental protected areas, but that has the Paranaguá Port, one of the greatest Brazilian port and a potential source for introduction of $L$. fortunei.

Moreover, our study supports a widespread presence of this species in the main basins in the Paraná state. Some studies have already detected the golden mussel presence in some sites in Tibagi River and Piquiri River basins [50], [59], and our study expand its presence for a wider stretch of these basins, with a great prevalence in the last. In the Ivaí River, although never reported before, we also found a high number of sites with $L$. fortunei eDNA and a high prevalence in the sampled sites (about $50 \%$ ). Finally, our study supports a wider distribution of the species in the Iguaçu River basin than previous reported. Thus, added to the bibliographic records, eDNA, larvae and adults of golden mussel have been detected in 118 sites along the state, what increase $320 \%$ the number of sites with its previous presence in Paraná state. 
Although is possible that the species does not present established populations in these sites where only larvae or eDNA were detected, these results support that the golden mussel propagules have been intensively transferred all over Paraná, especially through anthropic actions. The main, but not only, dispersion vectors inside the state are fish boats without proper sanitization and sand transportation (both by human activities), and fishes that feed on the species but not digest all of the individuals [57].

The presence of $L$. fortunei causes impacts in biodiversity and economic losses for hydroelectrical power plants and water treatment plants, that include decrease of equipment efficiency, need for maintenance and cleaning of plants, besides operational risks [7], [10]. Thus, considering the potential impacts of the golden mussel, the present results support a worrying scenario of the golden mussel distribution in Paraná state, that has been rapidly getting worse. In this context, developing strategies for the prevention and/or mitigation of its negative impacts in Paraná and other Brazilian states is essential [7], [10].

When prevention fails, it is necessary to apply very early all the efforts for a potential invasive species eradication, and it is why actions for early detection is highly recommended. Especially for terrestrial organisms, plants, for example, it has been possible to eradicate entire populations (but the costs are higher than prevention, either way) [61]. The effectiveness of eradication programs depends on several factors, and the stage of the invasion process is determinant. The later eradication programs start, lower are the chances of success [62], [63]. From then on, the control and mitigation of impacts take place, and the costs increase again. In the case of $L$. fortunei, controlling its populations inside facilities has been challenging, once most of methods proposed have partial efficiency and/or environmental risks [18], [19], [64]-[67]. In this way, monitoring the species presence and the early detection are keys for its management, once allow the development of proactive strategies that avoid the establishment of its populations and prevent great damages into the facilities.

Moreover, monitoring $L$. fortunei with eDNA presents a great potential for a low cost, precise, efficient and reliable tool. Once the markers were designed for amplify small mitochondrial DNA fragments, more abundant in the cell than nuclear DNA [68], they are able to detect even few copies of $L$. fortunei DNA present in the environment, and offer higher sensitivity than other markers (e.g. sanger DNA sequencing, larval detection markers) [33]-[35]. Furthermore, eDNA sampling requires only a small sample of water that can be easily collected and preserved at freezer. These particularities allowed us to perform the wider $L$. fortunei prospection in Paraná state with only few inconclusive samples.

Similarly, this efficient low-cost method have great potential to be used in a broader biological invasion's context, encompassing another invasive aquatic species in Paraná state and other Brazilian watersheds. Invasive bivalves besides L. fortunei (e.g. Corbicula fluminae [69], fish [70], [71], and aquatic plants [72] with potential for ecological and economical damages have been found in this region.

Finally, eDNA presents great importance for detect and monitoring the golden mussel presence and possible vectors of introduction and dispersion, enabling actions to be taken faster and more efficiently to prevent and mitigate problems. The detection of introduction and dispersion cores (sites with high propagule pressure) is essential to allow more targeted interventions, e.g. intensify inspections, institution of local environmental education and awareness programs, and environmental regulation reviews. Considering that, and the main species introduction and vectors, we recommend that marinas and ports should be regularly and continuously monitored for $L$. fortunei eDNA, as well as ballast waters, one of the main sources for aquatic species new introductions, including L. fortunei [62], [73], [74]. Ships and boats that navigate in brackish and freshwater, even as marine waters, should also be assessed for golden mussel DNA presence in the water taken from the water bodies and used for diverse purposes, like fishing lure and transport of juvenile fish.

Funding: This research was funded by SANEPAR (Paraná Water Utility).

Acknowledgments: We acknowledge for the support SANEPAR and all their technicians that performed the samplings all over the state, LACTEC (Institute of Technology for Development) for infrastructure and human resources, Luciana Patella for her help with laboratory work and contributions to the analyses process, and finally the reviewer for the great notes.

Conflicts of Interest: The authors declare no conflict of interest. Funders had the important role in the samples, performed by previous instructed technicians by the authors. 


\section{REFERENCES}

1. Darrigran G, Pastorino G. Ther recent introduction of a freshwater asiatic bivalve, Limnoperna fortunei (Mytilidae) into South America. The Veliger. 1995;38(2):171-5.

2. Oliveira MD, Campos MCS, Paolucci ES, Mansur MCD, Halminton S. Colonization and Spread of Limnoperna fortunei in South America. In: Boltovskoy D, editor. Limnoperna Fortunei Invading Nature - Springer Series in Invasion Ecology, vol 10. Springer, Cham; 2015. p. 333-55.

3. Darrigran G, Drago IE. Invasion of the exotic freshwater mussel Limnoperna fortunei (Dunker, 1857) (Bivalvia: Mytilidae) in South America. Nautilus (Philadelphia). 2000;114(2):69-73.

4. Boltovskoy D, Correa N, Cataldo D, Sylvester F. Dispersion and ecological impact of the invasive freshwater bivalve Limnoperna fortunei in the RI' o de la Plata watershed and beyond. Biol Invasions. 2006;8:947-63.

5. Bergonci PEA, Mansur MCD, Pereira D, Santos CP Dos. Population sampling of the golden mussel, Limnoperna fortunei ( Dunker , 1857 ), based on artificial ceramic substrate. Biotemas. 2009;22(3):85-94.

6. Pastorino G, Darrigran G, Martin, Lunaschi L. Limnoperna fortunei (Dunker, 1857) (Mytilidae), nuevo bivalvo invasor en aguas del Rio de la Plata. Neotropica. 1993;39:101-2.

7. Gustavo D, Mansur MD. Introdução e dispersão do Limnoperna fortunei. In: G, Darrigran CD, editors. Introdução a Biologia das Invasões O Mexilhão Dourado na América do Sul: biologia, dispersão, impacto, prevenção e controle. São Carlos: Cubo Editora; 2009. p. 89-110.

8. Darrigran G, Damborenea C. A South American bioinvasion case history: Limnoperna fortunei (Dunker, 1857), the golden mussel. Amer Malac Bull. 2005;20:105-12.

9. O'Neill Jr. CR. Economic Impact of Zebra Mussels - Results of the 1995 National Zebra Mussel Information Clearinghouse Study. Gt Lakes Res Rev. 1997;3(1):35-44.

10. Boltovskoy D, Xu M, Nakano D. Impacts of Limnoperna fortunei on Man-Made Structures and Control Strategies: General Overview. In: Boltovskoy D, editor. Limnoperna fortunei - The Ecology, Distribution and Control of a Swiftly Spreading Invasive Fouling Mussel. Invading Nature - Springer Series in Invasion Ecology; 2015. p. 37593.

11. Claudi R, Oliveira MD de. Chemical Strategies for the Control of the Golden Mussel ( Limnoperna fortunei) in Industrial Facilities. In: Boltovskoy D, editor. Limnoperna fortunei - The Ecology, Distribution and Control of a Swiftly Spreading Invasive Fouling Mussel. Invading Nature - Springer Series in Invasion Ecology; 2015. p. 41741.

12. Perepelizin $\mathrm{P} \vee$, Boltovskoy D. Hot water treatment (chronic upper lethal temperature) mitigates biofouling by the invasive Asian mussel Limnoperna fortunei in industrial installations. Environ Sci Technol. 2011;45(18):7868-73.

13. Xu M, Darrigran G, Wang Z, Zhao N, Lin CC, Pan B. Experimental study on control of Limnoperna fortunei biofouling in water transfer tunnels. J Hydro-Environment Res [Internet]. 2015;9(2):248-58. Available from: http://dx.doi.org/10.1016/j.jher.2014.06.006

14. Pucherelli SF, Claudi R. Evaluation of the effects of ultra-violet light treatment on quagga mussel settlement and veliger survival at Davis Dam. Manag Biol Invasions. 2017;8(3):301-10.

15. Angonesi LG, Da Rosa NG, Bemvenuti CE. Tolerance to salinities shocks of the invasive mussel Limnoperma fortunei under experimental conditions. Iheringia - Ser Zool. 2008;98(1):66-9.

16. Montresor LC, Miranda-Filho KC, Paglia A, Luz DMR, Araújo JM, Silva MJ dos S, et al. Short-term toxicity of ammonia, sodium Hydroxide and a commercial biocide to golden mussel Limnoperna fortunei (Dunker, 1857). Ecotoxicol ans Environ Saf. 2013;92:150-4.

17. Netto OSM. Controle da incrustação de organismos invasores em materiais de sistemas de resfriamento de usinas hidrelétricas. Universidade Federal do Paraná; 2011.

18. Vinitha E, Veeramani P, Venugopalan VP. Chlorination for power plant biofouling control: Potential impact on entrained phytoplankton. Int J Environ Stud. 2010;67(4):515-30.

19. Pitelli R, Lopez L, Cruz C, Garlich N, Bonafé R, Pitelli R, et al. Avaliações ambientais, ecotoxicológicas e de corrosividade de fontes cloradas utilizadas na prevenção da incrustação de mexilhão dourado (Limnoperna fortunei) em usinas hidrelétricas. In: XVIII ERIAC - Décimo Oitavo Encontro Regional Ibero-americano do CIGRE. Foz do Iguaçu; 2019. p. 9.

20. Hosler DM. Early detection of dreissenid species: Zebra/Quagga mussels in water systems. Aquat Invasions. 2011;6(2):217-22.

21. Darrigran G, Boeger W, Damborenea C, Maroñas M. Evaluation of sampling and analysis techniques for early detection of Limnoperna fortunei (Mytilidae) in limit areas of its distribution. Brazilian J Biol. 2009;69(3):979-80.

22. Ruiz GM, Hines AH. The Risk of Nonindigenous Species Invasion in Prince William Sound Associated with Oil Tanker Traffic and Ballast Water Management: Pilot Study. Regional Citizens' Advisory Council of Prince William Sound; 1997. p. 47.

23. Counihan TD, Bollens SM. Early detection monitoring for larval dreissenid mussels: how much plankton sampling is enough? Environ Monit Assess. 2017;189(3). 
24. Pestana D, Pie MR, Ostrensky A, Boeger WA, Andreoli C, Franceschi F, et al. Seasonal Variation in Larval Density of Limnoperna fortunei (Bivalvia, Mytilidae) in the Iguaçu and Paraná Rivers, in the Region of Foz do Iguaçu, Paraná, Southern Brazil. Braz arch biol technol. 2008;51(3):607-12.

25. Canzi C, Fialho NS, Bueno GW. Monitoring and occurrence of golden mussel (Limnoperna fortunei) in the Itaipu Hydroelectric Power Plant, Paraná, (BR). Rev lbero-Americana Ciências Ambient Aquidabã. 2014;5(2):117-22.

26. Piedras SRN, Bager A, Corrêa F. Ocorrência de Limnoperna fortunei (DUNKER, 1857) (MYTILIDAE) durante um período de salinização do baixo arroio Pelotas, Pelotas, Rio Grande do Sul. B Inst Pesca. 2005;33(1):121-5.

27. Johnson LE. Enhanced early detection and enumeration of zebra mussel (Dreissena spp.) veligers using crosspolarized light microscopy. Hydrobiologia. 1995;312(2):139-46.

28. Darling JA, Blum MJ. DNA-based methods for monitoring invasive species: A review and prospectus. Biol Invasions. 2007;9(7):751-65.

29. Pie MR, Boeger WA, Patella L, Falleiros RM. A fast and accurate molecular method for the detection of larvae of the golden mussel Limnoperna fortunei (Mollusca: Mytilidae) in plankton samples. J Molluscan Stud. 2006;72(2):218-9.

30. Boeger WA, Pie MR, Falleiros RM, Ostrensky A, Darrigran G, Mansur MCD, et al. Testing a molecular protocol to monitor the presence of golden mussel larvae (Limnoperna fortunei) in plankton samples. J Plankton Res. 2007;29(11):1015-9.

31. Rees HC, Maddison BC, Middleditch DJ, Patmore JRM, Gough KC. The detection of aquatic animal species using environmental DNA - a review of eDNA as a survey tool in ecology. J Appl Ecol. 2014;51(5):1450-9.

32. Herder J, Valentini A, Bellemain E, Dejean T, Delft J van, Philip Thomsen F, et al. Environmental DNA a review of the possible applications for the. 2014;(October):113.

33. Ficetola GF, Miaud C, Pompanon F, Taberlet P. Species detection using environmental DNA from water samples. Biol Lett. 2008;4(4):423-5.

34. Dejean T, Valentini A, Miquel C, Taberlet P, Bellemain E, Miaud C. Improved detection of an alien invasive species through environmental DNA barcoding: The example of the American bullfrog Lithobates catesbeianus. J Appl Ecol. 2012;49(4):953-9.

35. Dejean T, Valentini A, Duparc A, Pellier-Cuit S, Pompanon F, Taberlet P, et al. Persistence of environmental DNA in freshwater ecosystems. PLoS One. $2011 ; 6(8): 8-11$.

36. Jerde CL, Mahon AR, Chadderton WL, Lodge DM. "Sight-unseen" detection of rare aquatic species using environmental DNA. Conserv Lett. 2011;4(2):150-7.

37. Foote AD, Thomsen PF, Sveegaard S, Wahlberg M, Kielgast J, Kyhn LA, et al. Investigating the Potential Use of Environmental DNA (eDNA) for Genetic Monitoring of Marine Mammals. PLoS One. 2012;7(8):2-7.

38. Lance RF, Carr MR. Detecting eDNA of invasive Dreissenid mussels: Report on capital investment project. 2012;(June):1-9. Available from: http://el.erdc.usace.army.mil/elpubs/pdf/ansrp12-2.pdf

39. Olson ZH, Briggler JT, Williams RN. An eDNA approach to detect eastern hellbenders (Cryptobranchus a . alleganiensis) using samples of water. Wildl Res. 2012;39:629-36.

40. Herder J, Valentini A, Kranenbarg J. Detectie van grote modderkruipers met behulp van Environmental DNA. H2O. 2012;3:25-7.

41. Takahara T, Minamoto T, Doi H. Using Environmental DNA to Estimate the Distribution of an Invasive Fish Species in Ponds. PLoS One. 2013;8(2).

42. AJ, Persaud T, Wolfe BA, Bauman JM. Noninvasive method for a statewide survey of eastern hellbenders cryptobranchus alleganiensis using environmental DNA. Int J Zool. 2013;2013.

43. Pilliod DS, Goldberg CS, Arkle RS, Waits LP. Factors influencing detection of eDNA from a stream-dwelling amphibian. Mol Ecol Resour. 2014;14(1):109-16.

44. Pie MR, Ströher PR, Agostinis AO, Lopes RB, Sfeir MZT, Ostrensky A. Development of a real-time PCR assay for the detection of the golden mussel (limnoperna fortunei, mytilidae) in environmental samples. An Acad Bras Cienc. 2017;89(2):1041-5.

45. Xia Z, Zhan A, Gao Y, Johnson M. Early Detection of a Highly Invasive Bivalve Based on Environmental DNA: Methods Development and Optimization Early detection of non-indigenous species ( NIS ) - When NIS are rare, they ' re easier to manage.

46. Mansur MCD, Santos CP Dos, Darrigran G, Heydrich I, Callil CT, Cardoso FR. Primeiros dados quali-quantitativos do mexilhão-dourado, Limnoperna fortunei(Dunker), no Delta do Jacuí, no Lago Guaíba e na Laguna dos Patos, Rio Grande do Sul, Brasil e alguns aspectos de sua invasão no novo ambiente. Rev Bras Zool. 2003;20(1):7584.

47. Zanella O, Marenda L. Ocorrência de Limnoperna fortunei na Central Hidrelétrica de Itaipu. In: 5 Congresso Latinoamericano de Malacologia. São Paulo: Resumos. Instituto Butantan/Instituto de Biociências, USP; 2002. p. 41.

48. Takeda MA, Mansur MCD, Fujita DS, Bibian JP. Ocorrência da espécie invasora de Mexilhão Dourado, Limnoperna fortunei (Dunker, 1857) em dois pequenos reservatórios próximos a Curitiba, PR. Acta Biológica Leopoldensia. 2003;25(2). 
49. Frehse F de A, Andrade PDB, Vitule JRS. Absence of the invasive golden mussel in a reservoir near Curitiba, Brazil: A possible case of invasion failure. Neotrop Biol Conserv. 2018;13(1):86-9.

50. Pestana D, Ostrensky A, Tschá MK, Boeger W. Prospecção do molusco invasor Limnoperna fortunei (DUNKER, 1857) nos principais corpos hídricos do estado do Paraná, Brasil. Pap Avulsos Zool. 2010;50(35):553-9.

51. Borges PD. Limnoperna fortunei (BIVALVIA: MYTILIDAE) e o setor elétrico brasileiro: distribuição, impactos, estudo de caso da dispersão no rio Iguaçu e teste de protocolo de uso de larvas na caracterização do perfil genético de populações [Internet]. Universidade Federal do Paraná; 2014. Available from: http://dx.doi.org/10.1016/j.biochi.2015.03.025\%0Ahttp://dx.doi.org/10.1038/nature10402\%0Ahttp://dx.doi.org/10. 1038/nature21059\%0Ahttp://journal.stainkudus.ac.id/index.php/equilibrium/article/view/1268/1127\%0Ahttp://dx. doi.org/10.1038/nrmicro2577\%0Ahttp://

52. Garcia DAZ, Orsi ML, Casimiro ACR, Kurchevski G. Registros de Ocorrência de Limnoperna fortunei no Médio e Baixo Paranapanema: Uma Ameaçã as Suas Águas. Vol. 2, Ecologia. São Lourenço - MG; 2009.

53. Littlewood D, Olson R. No Interrelationships of the Platyhelminthes. The Syst Assoc Spec. 2001;60:365.

54. Xia Z, Zhan A, Gao Y, Zhang L, Haffner GD, Maclsaac HJ. Early detection of a highly invasive bivalve based on environmental DNA (eDNA). Biol Invasions. 2017;20(2):437-47.

55. Ratnasingham S, Hebert PDN. BOLD: The Barcode of Life Data System: Barcoding. Mol Ecol Notes. 2007;7(3):355-64.

56. Pestana D, Ostrensky A, Tschá MK, Boeger W a. P I (d, 1857) p , b. Papéis Avulsos Zool (São Paulo). 2010;50(34):553-60.

57. Belz CE, Darrigran G, Netto OSM, Boeger WA, Ribeiro Jr. PJ. Analysis of Four Dispersion Vectors in Inland Waters: The Case of the Invading Bivalves in South America. J Shellfish Res. 2012;31(3):777-84.

58. IBAMA. Diagnóstico sobre a invasão do mexilhão-dourado (Limnoperna fortunei) no Brasil. Relatório da Consulta Pública [Internet]. Instituto Brasileiro do Meio Ambiente e dos Recursos Naturais Renováveis - IBAMA, Ministério do Meio Ambiente - MMA. 2017. Available from: https://www.ibama.gov.br/phocadownload/biodiversidade/mexilhao-dourado/2017/2017-10-02-consulta-publicamexilhao-dourado-2.pdf

59. Ferraz JD, Gois EMV, Yabu MHS, Garcia DAZ, Marques ACV, Casimiro ACR, et al. Malacofauna bentônica do Lago Igapó , Londrina ( Paraná , Brasil ), com ênfase na espécie invasora mexilhão-dourado Limnoperna fortunei ( Dunker, 1857 ) Benthic malacofauna from the Igapó Lake, Londrina ( Paraná, Brazil ), with emphasis on the invasive. Semin Ciências Biológicas e da Saúde, Londrina. 2021;42(1):3-14.

60. Pessotto MA, Nogueira MG. More than two decades after the introduction of limnoperna fortunei (Dunker 1857) in La Plata Basin. Brazilian J Biol. 2018;78(4):773-84.

61. Rejmánek M, Pitcairn MJ. When is eradication of exotic pest plants a realistic goal? Turn tide Erad invasive species. 2002;249-53.

62. Darrigran G, Damborenea C. Introdução a Biologia das Invasões. O Mexilhão Dourado na América do Sul: biologia, dispersão, impacto, prevenção e controle. Cubo Editora. Darrigran G, Damborenea C, editors. Biologia. AES Tietê; 2009. 245 p.

63. Darrigran GA, Damborenea C. Strategies and Measures to Prevent Spread of Invasive Species. In: Boltovskoy D, editor. Limnoperna fortunei, Invading Nature - Springer Series in Invasion Ecology. Springer International Publishing Switzerland; 2015. p. 357-71.

64. Meyer ST. O uso de cloro na desinfecção de águas, a formação de trihalometanos e os riscos potenciais à saúde pública. Cad Saude Publica. 1994;10(1):99-110.

65. Pianowski EH, Janissek PR. Desinfecção de efluentes sanitários com uso de cloro: avaliação da formação de trihalometanos. SANARE - Rev técnica da SANEPAR [Internet]. 2003;20:6-17. Available from: https://pdfs.semanticscholar.org/3cad/eb80d4cd6bed0b981f83a1098de5ed0580c7.pdf

66. Ribeiro DDC, Pelli A. Toxicidade aguda e crônica do MXD-100 em camarões de água doce Macrobrachium amazonicum (Heller, 1862) (cristacea, palaemonidae) em condições experimentais. Uningá Rev. 2011;08(2):98102.

67. Claudi R, Oliveira MD. Chemical strategies for the control of the golden mussel (Limnoperna fortunei) in industrial facilities. In: Boltovskoy D, editor. Limnoperna Fortunei: The Ecology, Distribution and Control of a Swiftly Spreading Invasive Fouling Mussel. Invading Nature - Springer Series in Invasion Ecology Vol. 10; 2015. p. 41741.

68. Freeland JR, Kirk H, Petersen S. Molecular Ecology. Second Edi. Molecular Ecology. John Wiley \& Sons, Ltd.; 2011. 449 p.

69. Ragonha FH, Pinha GD, Petsch DK, Mansur MCD, Takeda AM. First records of Freshwater Bivalves of Ilha Grande National Park, Paraná, Brazil. Iheringia Série Zool. 2014;104(1):14-20.

70. Frota A, Deprá G de C, Petenucci LM, Da Graça WJ. Inventory of the fish fauna from Ivaí River basin, Paraná State, Brazil. Biota Neotrop. 2016;16(3).

71. Ribeiro VR, Silva PRL da, Gubiani ÉA, Faria L, Daga VS, Vitule JRS. Imminent threat of the predator fish invasion Salminus brasiliensis in a Neotropical ecoregion: eco-vandalism masked as an environmental project. Perspect Ecol Conserv [Internet]. 2017;15(2):132-5. Available from: http://dx.doi.org/10.1016/j.pecon.2017.03.004 
72. Souza DC, Cunha ER, Murillo R de A, Silveira MJ, Pulzatto MM, Dainez-Filho MS, et al. Species inventory of aquatic macrophytes in the last undammed stretch of the Upper Paraná River, Brazil. Acta Limnol Bras. 2017;29.

73. Gonçalves AA. Bioinvasion through ballast water: a global concern. J Ocean Technol. 2013;8(Special Issue):88118.

74. Darrigran G, Damborenea C, Drago EC, de Drago IE, Paira A, Archuby F. Invasion process of Limnoperna fortunei (Bivalvia: Mytilidae): The case of Uruguay river and emissaries of the Esteros del Iberá Wetland, Argentina. Zoologia. 2012;29(6):531-9.

2021 by the authors. Submitted for possible open access publication under the terms and conditions of the Creative Commons Attribution (CC BY NC) license (https://creativecommons.org/licenses/by-nc/4.0/). 